\title{
Chemotaxis of Physarum polycephalum towards Carbohydrates, Amino Acids and Nucleotides
}

\author{
By I. CHET, A. NAVEH AND Y. HENIS \\ Department of Plant Pathology and Microbiology, The Hebrew University, \\ Faculty of Agriculture, Rehovot, Israel
}

(Received I6 February 1977; revised 25 April 1977)

\begin{abstract}
A simple method for studying the chemotactic responses of the plasmodium of Physarum polycephalum was designed. A positive chemotactic response was detected towards the sugars D-glucose, lactose, D-maltose and D-galactose, the amino acids L-leucine, L-serine and DL-phenylalanine, and the nucleotide uracil. The significance of chemotaxis in Physarum is discussed.
\end{abstract}

\section{INTRODUCTION}

The fascinating phenomena of chemotaxis, movement and plasma shuttle streaming in plasmodia of myxomycetes have attracted the attention of many scientists for almost a century (Pfeffer, I883; Kamiya, I959; Carlile, I970; Chet \& Mitchell, 1976).

In recent years, analysis of receptors and a better understanding of their mode of action in bacteria has been achieved (Adler, 1975). The role of chemotaxis in cell aggregation of the cellular slime-mould was comprehensively reviewed by Bonner (197I) and his collaborators. The plasmodium of acellular slime-moulds shows a similar response towards chemical attractants (Konijn, I973). There has been much interest in the biochemical and physiological analogies between the plasmodium of acellular slime-moulds and the muscular systems in vertebrates (Kessler, 1972; Komnick, Stockem \& Wohlfarth-Botterman, 1973).

In this paper we describe a system developed to measure chemotactic responses towards carbohydrates, amino acids and nucleotides.

\section{METHODS}

Microplasmodia of Physarum polycephalum (Madison strain $\mathrm{M}_{3} \mathrm{C}$ ) were grown in $250 \mathrm{ml}$ flasks containing $20 \mathrm{ml}$ semi-defined nutrient solution prepared according to Daniel \& Baldwin (1964), and incubated for 48 to $72 \mathrm{~h}$ at $24^{\circ} \mathrm{C}$ in darkness on a reciprocal shaker ( 70 cycles $\mathrm{min}^{-1}$ ). The microplasmodia were centrifuged at $150 \mathrm{~g}$ for $5 \mathrm{~min}$, and washed twice in salt solution (Daniel \& Baldwin, 1964). Samples (0. $\mathrm{I} \mathrm{ml}$ ) of microplasmodia were placed on sterile medium containing $0.02 \mathrm{M}$-phosphate buffer $(\mathrm{pH} 6.4)$ and $2 \%(\mathrm{w} / \mathrm{v})$ agar (Difco). Within $\mathrm{I} 2 \mathrm{~h}$ fusion of the microplasmodia took place, and after $24 \mathrm{~h} \mathrm{r} \cdot 0 \times 0.5 \mathrm{~cm}$ pieces of plasmodium were cut and transferred to the test system.

The 'star' configuration of the test system was cut in the agar ( $12 \mathrm{ml} 0.02 \mathrm{M}$-phosphate buffer pH 6.4 and $\mathrm{I} \%$ agar) as shown in Fig. I. Test substance $(0 . \mathrm{I} \mathrm{ml,} 0.05 \mathrm{M})$ was applied to one of the four holes $(8 \mathrm{~mm}$ diam.) cut in the agar. The other three holes contained the control buffer solution.

The glucose gradients formed in the agar were measured by covering its surface with $5 \mathrm{ml}$ of solution containing I mg 2,3,5-triphenyltetrazolium chloride $\mathrm{ml}^{-1}$ (Sigma) for Io min in darkness (Stahal \& Kaltenbach, 1965). The reagent was washed off with water. Strips of agar $(1 \times 5 \mathrm{~cm})$ were cut and placed on microscope slides and the colour intensity was recorded by a Varian spectrophotometer model 635 (Varian Techtron, Mulgrave, Australia) at $600 \mathrm{~nm}$. This test showed that a gradient of I to $2 \mu \mathrm{g} \mathrm{ml}^{-1} \mathrm{~mm}^{-1}$ between 40 to $60 \mu \mathrm{g}$ glucose $\mathrm{ml}^{-1}$ was sufficient for a positive chemotactic response. Such a gradient was reached $30 \mathrm{~mm}$ from the hole containing the attractant after $24 \mathrm{~h}$ of diffusion. A positive chemotactic response was 


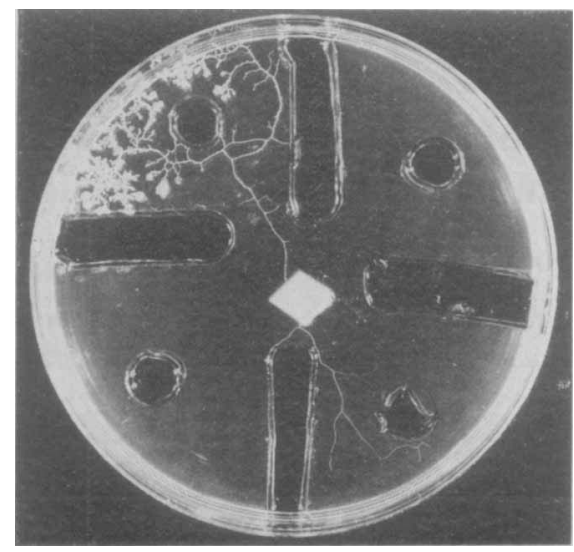

Fig. I. Positive chemotaxis of a plasmodium of Physarum polycephalum towards $0.1 \mathrm{ml}$ of $0.05 \mathrm{M}-$ glucose in the 'star' chemotaxis test, carried out in a $9 \mathrm{~cm}$ diam. Petri dish. The other three holes contained $0.02 \mathrm{M}$-phosphate buffer as controls.

recorded when the plasmodium moved towards the hole containing the test substance and touched it within $24 \mathrm{~h}$.

Data of all tests were analysed for distribution of frequency of events at a significance level of 0.05 . The most probable outcome of random migration gave the result of one positive response in four successful tests. A successful test was recorded when the plasmodium touched any of the four holes within $24 \mathrm{~h}$. All tests were carried out at $24{ }^{\circ} \mathrm{C}$ in darkness.

\section{RESULTS AND DISCUSSION}

Our method of measuring chemotactic responses improves that previously used (Madelin, Audus \& Knowles, I975; Knowles \& Madelin, 1975) in that the 'star' cuttings prevent diffusion and mixing of substances in the different holes (Fig. I). Using this test we have shown that the plasmodium of Physarum polycephalum responds positively to the monosaccharides D-glucose and D-galactose, and to the disaccharides lactose and D-maltose. With cellobiose and D-mannitol, a response was suspected but was not proved (Table I). These results are in accord with those reported by Carlile (1970), except for the absence of chemotaxis to mannose which may be due to the different strain tested.

In contrast to the effect of glucose and galactose analogues on bacterial chemotaxis (Adler, 1969), no effect of $\alpha$-methylglucoside, 2-deoxyglucose or raffinose on plasmodial chemotactic movement was observed.

Out of ro amino acids tested, only L-leucine, DL-phenylalanine and L-serine were attractants (Table I). Similarly, zoospores of Allomyces sp. showed a positive chemotactic response to L-serine (Carlile \& Machlis, 1965; Machlis, 1969). The effective response of bacterial membrane receptors to the amino acid L-serine was demonstrated by Adler (1975) and Mesibov \& Adler (1972).

In view of the active nucleic acid metabolism which presumably occurs during growth of the plasmodia of $P$. polycephalum (Rusch, 1970), the failure of most of the tested nucleotides and related compounds to attract the plasmodium was unexpected. Positive chemotaxis was confirmed only with uracil (Table I).

Recently, Carlile (1976) concluded that specific receptors for attractants are present in $P$. polycephalum. The ability to distinguish between compounds affecting motility and chemotaxis in the plasmodium of $P$. polycephalum may be helpful in the biochemical and physiological research on the principles of chemotactic movement of eukaryotic organisms. 
Table I. Chemotactic response of a plasmodium of Physarum polycephalum to some carbohydrates, amino acids and nucleotides

The 'star' test was used with phosphate buffer as the control solution.

\begin{tabular}{|c|c|c|c|c|}
\hline Substrate $(0.05 \mathrm{M})$ & $\begin{array}{l}\text { No. of } \\
\text { successful } \\
\text { tests }\end{array}$ & $\begin{array}{c}\text { No. of } \\
\text { positive } \\
\text { responses }\end{array}$ & $\begin{array}{l}\text { Probability } \\
\text { of results* } \\
(\%)\end{array}$ & Response $\dagger$ \\
\hline \multicolumn{5}{|l|}{ Carbohydrates } \\
\hline Glucose & 10 & 9 & $2.7 \times 10^{-4}$ & + \\
\hline Lactose & IO & 7 & $3.08 \times 10^{-1}$ & + \\
\hline Maltose & IO & 6 & $I \cdot 6$ & + \\
\hline Galactose & 10 & 6 & $1 \cdot 6$ & + \\
\hline Cellobiose & IO & 5 & $5 \cdot 8$ & 0 \\
\hline Mannitol & 15 & 6 & $9 \cdot 1$ & 0 \\
\hline Sucrose & 15 & 4 & 85 & 0 \\
\hline Fructose & IO & 4 & $14 \cdot 6$ & 0 \\
\hline Rhamnose & 15 & 3 & 100 & 0 \\
\hline Ribose & I5 & 5 & 16.5 & 0 \\
\hline D-Arabinose & 15 & 5 & $16 \cdot 5$ & 0 \\
\hline Xylose & 5 & I & 100 & 0 \\
\hline$\alpha$-Methylglucoside & I5 & 5 & $16 \cdot 5$ & o \\
\hline 2-Deoxyglucose & I5 & 5 & $16 \cdot 5$ & 0 \\
\hline Mannose & 5 & 2 & $23 \cdot 6$ & 0 \\
\hline Raffinose & 5 & 2 & $23 \cdot 6$ & 0 \\
\hline \multicolumn{5}{|l|}{ Amino acids } \\
\hline DL-Phenylalanine & 15 & IO & $6 \times 10^{-3}$ & + \\
\hline L-Leucine & 5 & 4 & $1 \cdot 4$ & + \\
\hline L-Serine & 13 & 9 & $3 \times 10^{-2}$ & + \\
\hline L-Histidine & 5 & I & 100 & 0 \\
\hline L-Cysteine & 5 & I & 100 & 0 \\
\hline L-Alanine & 5 & I & 100 & 0 \\
\hline L-Threonine & 5 & 2 & $23 \cdot 6$ & 0 \\
\hline L-Proline & 5 & 2 & $23 \cdot 6$ & 0 \\
\hline L-Arginine & 10 & 4 & $14 \cdot 6$ & 0 \\
\hline L-Isoleucine & I0 & I & 100 & 0 \\
\hline Peptone & IO & 6 & $\mathrm{I} \cdot 62$ & + \\
\hline \multicolumn{5}{|l|}{ Nucleotides } \\
\hline Uracil & 5 & 4 & $I \cdot 4$ & + \\
\hline Uridylic acid & 5 & 0 & 100 & 0 \\
\hline Adenylic acid & 5 & $\mathbf{I}$ & 100 & 0 \\
\hline Thymine & 5 & I & 100 & 0 \\
\hline Adenine & 5 & 2 & 23.6 & 0 \\
\hline Uridine & 5 & I & 100 & 0 \\
\hline Cytosine & 5 & 2 & 23.6 & 0 \\
\hline Cytidine & 5 & 2 & $23 \cdot 6$ & 0 \\
\hline Thymidine & 5 & I & 100 & 0 \\
\hline Adenosine & 5 & 0 & 100 & 0 \\
\hline
\end{tabular}

* Probability ( $\%$ ) of the results being due to random migration.

$\dagger+$, Positive chemotaxis at the $5 \%$ significance level $(P=0.05)$; o, no significant response.

\section{REFERENCES}

Adler, J. (1969). Chemotaxis in bacteria. Science I66, I 588-I 597 .

ADLER, J. (1975). Chemotaxis in bacteria. Annual Review of Biochemistry 44, 34I-345.

BONNER, J. T. (1971). Aggregation and differentiation in the cellular slime molds. Annual Review of Microbiology 25, 75-92.

Carlile, M. J. (1970). Nutrition and chemotaxis in the myxomycete Physarum polycephalum: the effect of carbohydrates on the plasmodium. Journal of General Microbiology 63, $221-226$.

Carlile, M. J. (1976). Migration and chemotaxis in Physarum polycephalum. Third European Physarum Workshop, Bern, p. Io.

Carlile, M. J. \& Machlis, L. (1965). A comparative study of the chemotaxis of the motile phases of Allomyces. Journal of Bacteriology 58, 484490. 
Chet, I. \& Mitchell, R. (1976). Ecological significance of microbial chemotactic behavior. Annual Review of Microbiology 30, 22 I-239.

Daniel, J. W. \& Baldwin, H. H. (1964). Methods of culture for plasmodial myxomycetes. Methods in Cell Physiology 1, 9-4I.

Kamiya, N. (1959). Protoplasmic streaming. Protoplasmatologia 8, 3a, I-199.

KESSLER, D. (1972). On the location of myosin in the myxomycete Physarum polycephalum and its possible function in cytoplasmic streaming. Journal of Mechanochemistry and Cell Motility $\mathbf{1}$, I $25-137$.

Knowles, D. \& Madelin, M. F. (1975). Chemotactic and other responses of plasmodia of Badhamia utricularis to an extract of Stereum hirsutum and to certain other substances. Journal of General Microbiology 89, 235-244.

Komnick, W. S., Stockem, W. \& WohlfarthBotterman, K. E. (1973). Cell motility: mechanisms in protoplasmic streaming and amoeboid movement. International Review of Cytology 34, I69-249.

KoniJn, T. M. (1973). Chemotaxis and aggregation in slime molds. In Behaviour of Microorganisms, pp. 48-6I. Edited by A. Perez-Miravete. London: Plenum Press.

MaCHLIS, M. (1969). Zoospore chemotaxis in the watermold Allomyces. Plant Physiology 22, 126-136.

Madelin, M. F., Audus, F. \& Knowles, D. (1975). Attraction of plasmodia of the myxomycete, Badhamia utricularis, by extracts of the basidiomycete, Stereum hirsutum. Journal of General Microbiology 89, 229-234.

Mesibov, R. \& AdLeR, J. (1972). Chemotaxis towards amino acids in E. coli. Journal of Bacteriology 112, 2 I 5-226.

PfeFfER, W. (1883). Locomotrische Richtungsbewegung durch chemische Reize. Bericht der Deutschen botanischen Gesellschaft I, 524-533.

RusCH, H. P. (1970). Some biochemical events in the life cycle of Physarum polycephalum. Federation Proceedings 28, 176I-I770.

Stahal, E. \& Kaltenbach, U. (1965). Visualization of carbohydrates. In Thin-layer Chromatography - A Laboratory Handbook, pp. 466-475. London: Academic Press. 